\title{
A!
}

This is an electronic reprint of the original article.

This reprint may differ from the original in pagination and typographic detail.

Chliova, Myrto; Ringov, Dimo

Scaling Impact: Template Development and Replication at the Base of the Pyramid

Published in:

ACADEMY OF MANAGEMENT PERSPECTIVES

DOI:

10.5465/amp.2015.0010

Published: 01/02/2017

Document Version

Peer reviewed version

Please cite the original version:

Chliova, M., \& Ringov, D. (2017). Scaling Impact: Template Development and Replication at the Base of the Pyramid. ACADEMY OF MANAGEMENT PERSPECTIVES, 31(1), 44-62.

https://doi.org/10.5465/amp.2015.0010

This material is protected by copyright and other intellectual property rights, and duplication or sale of all or part of any of the repository collections is not permitted, except that material may be duplicated by you for your research use or educational purposes in electronic or print form. You must obtain permission for any other use. Electronic or print copies may not be offered, whether for sale or otherwise to anyone who is not an authorised user. 


\title{
Scaling Impact: Template Development and Replication at the Base of the Pyramid
}

MYRTO CHLIOVA

Aalto University School of Business

\section{DIMO RINGOV}

\author{
ESADE Business School
}

\begin{abstract}
We thank former co-editor-in-chief Timothy Devinney and two anonymous reviewers for their helpful and developmental feedback on an earlier draft of this paper.
\end{abstract}




\section{ABSTRACT}

In recent years, management scholars and practitioners have been advocating a more prominent role for business in economic and social development at the "base of the pyramid" (BoP), where more than 1 billion people subsist on less than $\$ 2$ a day. Yet, in both theory and practice, the development of financially sustainable and scalable business solutions for the BoP has been challenging. By integrating insights from the emerging BoP literature with extant research on the replication of organizational routines and templates, this study examines how the distinctive conditions of the BoP affect the development and replication of scalable business solutions for the world's poor. In particular, we identify key distinctive conditions of the BoP and develop an organizing framework of the mechanisms that facilitate the development and replication of viable and scalable business templates there. Our analysis contributes to BoP research by advancing understanding of the role of templates in economic and social development at the BoP as well as to research on the replication of organizational routines and templates by delineating the distinctive conditions and mechanisms that affect the development and replication of templates at the BoP.

Keywords: base of the pyramid, template replication, template development, scaling up, firm growth 
"Aravind can practice compassion successfully because it is run like a McDonald's, with assembly-line efficiency, strict quality norms, brand recognition, standardization, consistency, ruthless cost control and above all, volume." (Rosenberg, 2013)

An astounding 1 billion people at the base of the world's economic pyramid subsist on less than $\$ 2$ a day ${ }^{1}$. In response, scholars and practitioners have in recent years been advocating for a more prominent role of business and innovation in economic and social development in such "base of the pyramid" (BoP) environments (Bruton, Ketchen, \& Ireland, 2013; Prahalad, 2009; Yunus, 1998). A core underlying assumption behind this is that one can develop solutions that scale considerably and, thus, exert a positive social and economic impact for large numbers of people living in subsistence conditions (Anderson, Markides, \& Kupp, 2010; Austin, Stevenson, \& Wei-Skillern, 2006; Dees, Anderson, \& Wei-Skillern, 2004). Such BoP solutions are of interest for their ability to both benefit local BoP populations and become "at least in part, financially self-sustaining rather than relying exclusively upon ongoing donations or government grants” (Kistruck, Beamish, Qureshi, \& Sutter, 2013, p. 32).

Successful exemplars such as Aravind Eye Hospitals in India and BRAC in Bangladesh have fueled enthusiasm for the creation of scalable solutions at the BoP even further. For example, by replicating established templates with only minor adaptations, BRAC has grown to become the largest NGO in the world to target the BoP, serving 135 million people in 11 countries, with an astounding 70\% of its activities being financially sustainable (Davis, 2013). Likewise, Aravind

\footnotetext{
${ }^{1}$ http://iresearch.worldbank.org/PovcalNet/index.htm?1
} 
Eye Hospitals have famously adopted a "McDonald's approach," reaching a scale that allows them to conduct as many as $60 \%$ of the number of eye surgeries that the UK's National Health Service conducts each year, at a fraction of the cost (Rosenberg, 2013).

Yet the development and replication of financially sustainable solutions for the BoP seems to be problematic from both a practical and a scholarly perspective. Reality has lagged behind the rhetoric, and there are few examples of organizations targeting the BoP that have managed to grow significantly by replicating a successful recipe at a larger scale (Kayser \& Budinich, 2015; Kistruck, Sutter, Lount, \& Smith, 2012; London \& Hart, 2004). Furthermore, the BoP literature addresses the issue of replication in a fragmented way, largely ignoring theoretical developments related to replication in top of the pyramid (ToP) markets. In recent years, management scholars have contributed to a growing literature on the phenomenon of large-scale replication of templates in ToP markets (D'Adderio, 2014; Jensen \& Szulanski, 2007; Jonsson \& Foss, 2011; Winter \& Szulanski, 2001; Winter, Szulanski, Ringov, \& Jensen, 2012). A template is a working system of organizational routines that serve as the referent or guiding example for an organization that intends to grow by replication (Jensen \& Szulanski, 2007; Ringov, Liu, Jensen, \& Szulanski, 2016). At the ToP, the systematic replication of templates has been advocated as the main mechanism behind the large scale achieved rapidly by certain organizations, termed "replicating" organizations, that "grow by reproducing a productive system of practices in multiple locations" (Ringov et al., 2016, p. 3; Winter \& Szulanski, 2001; Winter et al., 2012). Yet there has been little scrutiny of the relevance of such theoretical guidance for organizations attempting growth through the development and replication of templates at the $\mathrm{BoP}$ (George, 
McGahan, \& Prabhu, 2012; Walsh, Kress, \& Beyerchen, 2005), a context that is distinct across a number of important dimensions. While growth through large-scale replication can be a complex and formidable task for organizations even at the ToP, BoP environments can pose significant additional challenges (Kistruck et al., 2012; London, Anupindi, \& Sheth, 2010; Rivera-Santos \& Rufín, 2010).

We thus explore the research question: How do the distinctive conditions at the $\mathrm{BoP}$ affect the development and replication of templates? By integrating insights from the emerging literature on the conditions present in BoP markets and the specific challenges to the development and growth of BoP markets (Kistruck et al., 2013; Kistruck et al., 2012; London \& Hart, 2004) with extant literature on the replication of organizational routines and templates (Jensen \& Szulanski, 2007; Szulanski \& Jensen, 2006; Winter \& Szulanski, 2001; Winter et al., 2012), we identify distinctive conditions at the BoP and develop a framework for understanding the mechanisms that facilitate the successful development and replication of templates at the BoP. In particular, we identify mechanisms related to the what, how, and where (Winter \& Szulanski, 2001, p. 733) as well as to the who of successfully developing and replicating templates in the specific context of the BoP.

We contribute to the BoP literature by advancing our current understanding of how business templates can be developed and replicated to promote social and economic development at the BoP, as well as to extant literature on the replication of organizational routines and templates by delineating distinctive conditions and mechanisms that affect the development and replication of templates at the BoP. Our framework improves understanding of the emerging yet fragmented 
area of replication of templates at the BoP by (a) synthesizing the most influential BoP contextrelated conditions that affect the development and replication of templates at the BoP, (b) delineating specific mechanisms that can affect the development and replication of templates at the BoP, and (c) linking the above context-related conditions and mechanisms with the types of replicating organizations most suitable to implement them. Thus, our integration of the two thus far disparate literatures of $\mathrm{BoP}$ and replication of routines and templates promotes the advancement of the scholarly conversation on and theoretical development of the highly consequential topic of BoP template replication, offering novel propositions and ideas that can be further developed and tested in future research.

\section{BASE OF THE PYRAMID AND TEMPLATE REPLICATION RESEARCH: NEED FOR ENHANCED CONVERSATION AND INTEGRATION}

The origins of the BoP proposition in the corporate and academic world can be traced back to the work of the late C. K. Prahalad and his colleagues (Prahalad, 2009; Prahalad \& Hammond, 2002), who promoted what at the time was a very unconventional proposition: that businesses could both do well and do good, make "a fortune" and simultaneously lift communities out of poverty by targeting poor and disenfranchised people at the BoP. This proposition challenged three prevailing assumptions: (1) that companies ought to focus only on their primary economic objective of maximizing shareholder value (Friedman, 2009); (2) that it is the exclusive responsibility and capability of governments, not business, to address poverty alleviation at the BoP; and (3) that there is no "fortune" or meaningful profits to be made by serving the extremely poor and treating them as one's target market. 
Counter to these assumptions, Prahalad and colleagues (Prahalad, 2009; Prahalad \& Hammond, 2002) affirmed that social impact and significant profits could be achieved simultaneously by business active at the $\mathrm{BoP}$ and that these two objectives were complementary, not contradictory. The optimistic message of concurrent profits and social impact struck a chord with big corporations, especially as high levels of market saturation and competition in ToP markets increasingly limited opportunities for fast-paced growth there (Anderson \& Markides, 2007; Kayser \& Budinich, 2015).

Since the original articulation of the $\mathrm{BoP}$ proposition, the emerging literature on the topic has undergone certain reorientations. The conceptualization of the $\mathrm{BoP}$ proposition has shifted from an initial emphasis on big corporations as the primary actors toward an examination of the role of smaller organizations as well. Multinational corporations were central to the initial BoP proposition, as they were assumed to have the resources and capabilities to succeed in reaching scale (Prahalad, 2009; Prahalad \& Hammond, 2002). Nevertheless, the implementation of the BoP proposition has in many cases proven to be more challenging than originally expected (Kistruck et al., 2012). As large corporations increasingly realize that profits at the BoP can be lower than expected and that successful BoP solutions may require very substantial adaptation of existing business models (London et al., 2010; Olsen \& Boxenbaum, 2009), they have become more critical of the idea, sometimes withdrawing from such projects or assigning them to their corporate social responsibility (CSR) departments.

Accordingly, discussions around ways to serve the BoP have gradually expanded to acknowledge the key role of smaller entrepreneurial organizations (Kolk, Rivera-Santos, \& 
Rufín, 2014) that may be able to develop scalable solutions for the BoP. Furthermore, scholars have been moving away from focusing on the poor solely as consumers at the BoP, in favor of "co-creation" models that endorse and integrate the poor as employees and collaborators (Hart \& Simanis, 2008; London et al., 2010; Schuster \& Holtbrügge, 2014), as the very real trade-offs that often exist between achieving social impact and economic profitability for organizations operating at the BoP are increasingly acknowledged (Bhatti \& Ventresca, 2012; Kistruck et al., 2013). Finally, a growing body of evidence suggests that most solutions for the BoP remain small, local innovations that fail to achieve large scale and, correspondingly, large-scale social impact (Kayser \& Budinich, 2015; London \& Hart, 2004; Starr, 2014). As a consequence, BoP researchers are increasingly calling for a more nuanced examination of the mechanisms under which the BoP proposition can reach the success and scale envisioned by its proponents (George et al., 2012; Kistruck et al., 2012; London et al., 2010).

At the same time, a parallel scholarly conversation in the management literature has focused on understanding growth through the development and large-scale replication of templates by organizations operating in ToP markets (D’Adderio, 2014; Jensen \& Szulanski, 2007; Jonsson \& Foss, 2011; Szulanski \& Jensen, 2006; Winter \& Szulanski, 2001; Winter et al., 2012). A template, as defined earlier, refers to a working system of organizational routines that serves as the referent or guiding example for an organization that intends to grow by replication (Jensen \& Szulanski, 2007; Ringov et al., 2016). In that literature, a strategy of growth through the largescale replication of a successful template is often viewed as a process that involves two recognizably different phases (Winter \& Szulanski, 2001). The first is a phase of development 
during which the business model that will serve as a template for replication is created and refined. The second is a phase of replication in which the template is stabilized and leveraged through large-scale replication (Winter \& Szulanski, 2001). ${ }^{2}$

This stream of research has documented that pursuing a strategy of organizational growth through large-scale, template-based replication is far from trivial. A "replication dilemma" often exists between the benefits of replicating a template precisely and the benefits of adapting it to fit the salient characteristics of new environments and incorporate new learning (Devinney, Midgley, \& Venaik, 2000; Winter \& Szulanski, 2001). Management scholars have long noted, and have provided evidence that, one size does not fit all, and hence purposeful local adaptation could be essential to achieving enhanced local performance (Ansari \& Zajac, 2010; Bartlett \& Ghoshal, 1999; Kostova \& Roth, 2002; Lawrence \& Lorsch, 1967). Research on the replication of routines and templates at the ToP has also provided arguments and evidence that organizations may also benefit from emphasizing the accurate replication of established templates and the conditions under which it may enhance local unit performance (e.g., Jensen \& Szulanski, 2007; Szulanski \& Jensen, 2006; Winter et al., 2012).

Recent research has provided further nuance to our understanding of the replication dilemma (D’Adderio, 2014; e.g., Jonsson \& Foss, 2011; Ringov et al., 2016), yet much work remains to

\footnotetext{
${ }^{2}$ It is important to note here that Winter and Szulanski (2001), following the seminal work of March (1991), used the terms exploration and exploitation to refer to the initial development of a template and its later replication. For the sake of parsimony and correspondence with customary business use, we have instead chosen to use the terms template development and template replication, respectively.
} 
be done to clarify the where, how, and what of successful replication (Winter \& Szulanski, 2001; Winter et al., 2012). In particular, it is striking that very little research in this stream of work has so far addressed how the development and replication of templates in BoP contexts may be different from ToP contexts (George et al., 2012; Sutter, Kistruck, \& Morris, 2014). Extant research on the replication of templates and routines has tended to overlook BoP contexts, while BoP research has largely neglected to make use of insights from the former literature (for exceptions see Kistruck, Webb, Sutter, \& Ireland, 2011; Sutter et al., 2014). While adaptation seems to be overly emphasized in accounting for growth of successful solutions at the BoP (London \& Hart, 2004; Schuster \& Holtbrügge, 2014; Seelos \& Mair, 2007), there are also reasons to expect that the development and replication of scalable templates might be particularly relevant there. Expert knowledge is bound to be very limited in $\mathrm{BoP}$ environments, so a proven template based on superior practices can yield performance benefits for firms that closely replicate it (Sutter et al., 2014).

Likewise, as Seelos and Mair (2007, p. 52) observed, "Nontraditional and uncertain environments increase the difficulties in understanding cause-and-effect relationships," which have been identified as a major impediment to local adaptations even in ToP contexts (Winter \& Szulanski, 2001). Indeed, in the field of practice, there are salient examples, such as Aravind Eye Hospitals, Kickstart, and Grameen Phone, of organizations that have developed a highly standardized template and have achieved rapid, large-scale replication (Kayser \& Budinich, 2015; Rosenberg, 2013; Seelos \& Mair, 2007). For example, Kickstart, selling irrigation pumps in sub-Saharan Africa, has gradually moved away from a model based on extensive adaptation 
toward the standardization of its template, in its efforts to achieve scale (Bhatti \& Ventresca, 2012). While the limited literature directly addressing the issue of growth in BoP contexts has hinted that these contexts possess distinctive conditions that affect replication (Kistruck et al., 2011; Sutter et al., 2014), it has provided little systematic theoretical guidance to link the distinctive conditions at the BoP to implications and mechanisms to develop and replicate templates at the BoP. We explore this question in the sections that follow.

\section{DISTINCTIVE CONDITIONS AT THE BOP}

The billion people included in the BoP reside across a wide range of geographies and cultures; thus, BoP contexts exhibit substantial variation across locations (Kayser \& Budinich, 2015; Rivera-Santos \& Rufín, 2010; Simanis \& Hart, 2009). Nevertheless, certain characteristics are common to these contexts and underlie the challenges to successfully developing and replicating templates there (Rivera-Santos, Holt, Littlewood, \& Kolk, 2015; Rivera-Santos \& Rufín, 2010). The distinctive conditions discussed below are not the only ones that characterize BoP markets, but have been considered particularly pertinent by scholars, under a variety of similar names, in previous work (London et al., 2010; Rivera-Santos \& Rufín, 2010; Zoogah, Peng, \& Woldu, 2015).

\section{Resource Scarcity}

BoP contexts are characterized by extreme resource scarcity (Seelos \& Mair, 2007; Sutter et al., 2014). On one hand, resource scarcity refers to BoP consumers' severely limited (or nonexistent) disposable income. Unmet needs alone are not sufficient for BoP templates to create viable market propositions (Simanis, 2011) — the target customers need to have some, even if 
minimal, disposable income as well (Kayser \& Budinich, 2015). The ultra-poor are usually unlikely to pay for anything outside the sphere of absolute necessity (Collins, Morduch, Rutherford, \& Ruthven, 2009). Thus, Simanis (2011, p. 111) highlighted non-consumption as the "defining condition of the BoP." As a result, the severe disposable income constraints prevalent in BoP markets (Seelos \& Mair, 2007) significantly limit the scope and nature of organizational templates that would be potentially viable there.

Another type of resource scarcity is related to the productive potential of BoP contexts. In ToP contexts, organizations can typically count on being able to access a wide variety of needed resources and capabilities through well-functioning markets (Helfat et al., 2009; Peteraf, 1993). Similar access to resources and capabilities is not widely available to organizations operating in the BoP. For example, producing locally can be difficult due to a generalized lack of productive facilities, including factories and technologically advanced machinery (Bhatti \& Ventresca, 2013; Zoogah et al., 2015). Moreover, many people in BoP contexts typically have not had enough opportunities to engage in paid employment that extends beyond rudimentary agricultural production, livestock rearing, or crafts (Karnani, 2007; Kistruck et al., 2011). As a result, a widespread lack of employment, experience, and competencies, and in particular of managerial experience/competencies, impinges on organizations' ability to find experienced employees to run their operations.

Furthermore, the lack of professional experience is compounded by low levels of education and high rates of illiteracy (Zoogah et al., 2015). In many extremely poor contexts, opportunities for publicly funded education are severely limited and private education is costly, perpetuating a 
vicious cycle of low education and limited employment choices (Sen, 1999). Thus, even when a template might be viable from the demand side, its development and replication could be constrained or derailed by supply-side factors. An illustrative case is that of HealthLine, a telemedicine venture established by the Grameen Bank in Bangladesh, whose rapid growth was thwarted by the lack of qualified doctors with which to staff their operations (de Carvalho, Klarsfeld, \& Lepicard, 2012).

\section{Institutional Voids}

A second striking characteristic of BoP contexts is the widespread lack of well-functioning institutions, namely the prevalence of institutional voids (Khanna \& Palepu, 1997; Mair \& Martí, 2009; Mair, Martí, \& Ventresca, 2011). In ToP contexts, it is easy for people to take for granted the enabling role of institutions (De Soto, 2003). Yet markets operate efficiently only within infrastructures that provide rules and routines for ensuring fair play and consistency. Institutional voids result where there is a dearth of established property rights, transparency, enforcement of contracts, and supervising or enabling intermediaries (Ault \& Spicer, 2014; Khanna \& Palepu, 1997; Mair et al., 2011). Enforceable property rights, for instance, are required for a wellfunctioning real estate market as well as for the use of real estate as a guarantee for other financial transactions, yet such rights are either nonexistent or not reliably enforced in many BoP contexts (De Soto, 2003; Portes \& Haller, 2005; Rivera-Santos \& Rufín, 2010).

Compounding this problem, most BoP economic activity is informal and unregistered by official authorities, limiting the extent to which regulations can be invoked and enforced in case of unethical behavior (Webb, Tihanyi, Ireland, \& Sirmon, 2009). Such gaps in information and 
lack of enforcement of sound business practices produce disincentives that thwart entrepreneurial initiative (Anokhin \& Schulze, 2009). For example, financial institutions cannot rely on customer information to offer services, nor can they make use of guarantees in case of suspended repayments of loans (Ghatak, 1999; Webb, Bruton, Tihanyi, \& Ireland, 2013). As a result, real estate also cannot be easily exchanged, and there is little incentive to invest in and develop it (Anderson et al., 2010; De Soto, 2003).

Concomitantly, individuals and organizations know that potential profits from entrepreneurship might not be protected in the event that business partners renege on their promises (Mair \& Martí, 2009). Moreover, corruption “provides perverse market incentives that distort resource allocation" (Zoogah et al., 2015, p. 14) and ultimately affects organizational efficiency (Sutter, Webb, Kistruck, \& Bailey, 2013). As a result, organizations operating in these contexts might need to bear substantial transaction costs (Khanna \& Palepu, 2000), which can make their involvement in markets less attractive. In sum, institutional voids are a key characteristic of BoP markets, particularly in developing countries, that - as we argue in the sections that follow—can be expected to have a significant effect on the development and replication of business templates at the BoP.

\section{Hybrid Motivation}

A third distinguishing condition of BoP contexts that may affect the development and replication of templates is related to the possible hybrid motivation of organizations active at the BoP. Organizations that "straddle the well-established categories of business and charity" are considered hybrid (Battilana, Sengul, Pache, \& Model, 2015, p. 1658) because they are 
frequently driven by dual motivations: that of social impact and that of economic profitability or at least sustainability (Austin et al., 2006; Mair \& Martí, 2006). Prahalad's (2009) assertion that concurrent economic profits and social impact are possible at the BoP implied that a hybrideconomic and prosocial - motivation would form the basis of business involvement at the BoP.

The argument that financial objectives need to be coupled with social objectives at the BoP has been echoed by subsequent research (Ansari, Munir, \& Gregg, 2012; George et al., 2012; London \& Hart, 2004). Indeed, it may be considered unethical to make profits from the extremely poor without contributing to their well-being. Frequent corporate misdemeanors have cultivated mistrust of businesses, which can backfire when local communities or international movements threaten to withdraw their "license to operate" locally (Hart \& Sharma, 2004; Kayser \& Budinich, 2015; Walsh et al., 2005). Indeed, Kistruck et al. (2011) have provided some evidence that big corporations are frequently viewed as illegitimate actors at the BoP.

Moreover, the high profitability advocated by Prahalad has not been an easy feat for organizations operating within such challenging contexts (Ansari et al., 2012; Ault \& Spicer, 2014; Karnani, 2007). Profits from BoP activity are often low, given that costs of development, production, distribution, and infrastructure building can be high relative to sales volume and margins (Kayser \& Budinich, 2015), while payback periods can be long (Simanis, 2011). Additionally, the win-win framing of the BoP propositions obscures the reality that trade-offs often exist between the dimensions of social impact and profits (Kistruck et al., 2013; London et al., 2010). Organizations that target higher-income segments in developing countries can be more profitable but less impactful than those targeting the BoP, and vice versa. For example, 
microcredit organizations that target the poorest customers typically earn lower total profits than those targeting bigger loan sizes and more prosperous clients (Cull \& Morduch, 2007; Hermes, Lensink, \& Meesters, 2011). Thus, extant theory and evidence suggest that organizations interested in developing and replicating scalable solutions for the BoP may benefit from a hybrid motivation (Battilana \& Dorado, 2010), combining social welfare and business orientation, if they are to find such an endeavor worthwhile in the long run.

\section{TEMPLATE DEVELOPMENT AT THE BOP}

We propose that organizations that are intent on reaching large scale in BoP markets should be particularly attentive to the implications of the aforementioned distinctive BoP conditions for both the initial development of potentially scalable BoP templates and for their later replication at scale. We argue that template development, during which the business model that will be used as a template for replication is created and refined (Winter \& Szulanski, 2001), is in itself a major challenge in BoP contexts, and subsequently a prerequisite for any efforts at large-scale replication. While the initial development of a template is an emergent process that cannot be completely predefined (March, 1991; Winter \& Szulanski, 2001), we identify mechanisms that affect the likelihood of successfully developing templates that will be viable and amenable to large-scale replication at the $\mathrm{BoP}$ given its distinctive conditions.

\section{Major Cost/Risk Reductions}

Extreme resource scarcity implies that developing an economically sustainable template at the $\mathrm{BoP}$ will be challenging. BoP templates typically have to incorporate business models and cost structures that are fundamentally different from the ones in place in similar product markets 
at the ToP (Olsen \& Boxenbaum, 2009; Prahalad, 2009). Yet an organization that has large-scale growth aspirations will also need to make sure that these new economics are encapsulated into an internally consistent, proven system of organizational routines (a template) that is replicable across a variety of new locations and environments. We propose that the likelihood of an organization developing a template amenable to large-scale replication at the BoP will be higher if the template development process is guided by the objective of offering significant reductions in the cost and risk experienced by the target customers compared to existing alternatives. We further propose that such cost and risk reductions can be achieved through cross-subsidization, aggregation of organizational functions, use of disruptive technology or distribution, and reductions in the upfront investment required from clients.

Cost can be reduced for clients if a template enables segmentation according to clients' paying ability and subsequent cross-subsidization across them. Cross-subsidization occurs when 'profit made on 'regular customers' is reinvested to compensate for the lower price paid by poorer customers" (Kayser \& Budinich, 2015, p. 94). Thus, the practices of audience segmentation and price differentiation, regularly implemented in ToP markets (Kotler \& Armstrong, 2010), are being adjusted to absorb the costs of servicing BoP customers at a discount or for free. Such cross-subsidization permits templates to cater to clients of different need and paying ability while maintaining the viability of the template in the aggregate. For instance, by maintaining a two-tiered pricing structure, partly targeted to paying customers and partly targeted to nonpaying customers, Aravind Eye Care was able to create a template that was both economically viable and replicable (Rangan \& Thulasiraj, 2007). Similar strategies have 
worked successfully for the Nicaraguan corrective glasses venture Asembis and for the Indian heart surgery hospitals Narayana Health (Kayser \& Budinich, 2015).

Organizations operating at the $\mathrm{BoP}$ can also drastically alter the economics underlying market failures by aggregating certain functions, if production and marketing costs had previously been distributed across poor, self-employed people, rendering transaction costs too high to bear by any single one of them. Larger organizations can build into their template a centralization of functions, thus achieving efficiencies that individual producers would not have been able to realize (Kistruck et al., 2013). For example, inefficiencies have long plagued local agricultural markets in sub-Saharan Africa, as individual production is extremely small-scale and farmers do not have the means or knowledge to invest in R\&D, storage, distribution, collective wholesaling, or forward contracting to international clients (Bell \& Milder, 2008; Kistruck et al., 2013; Thurow, 2013). As a result, organizations exploring the creation of viable agricultural markets in the BoP, such as One Acre Fund or Root Capital, have been able to achieve significant economies of scale and corresponding price reductions by cost-efficiently aggregating such functions within their templates. Microcredit organizations have similarly used aggregation of functions to provide group — instead of individual—credit to poor people, reducing prohibitive transactions costs to a considerable extent (Ghatak, 1999; Stiglitz, 1990).

Alternatively, costs can be reduced if a template is designed to include the absolute minimum product or service required at the BoP, stripped of additional features that are desirable and frequently taken for granted in ToP markets (Bhatti \& Ventresca, 2013; Christensen, Baumann, Ruggles, \& Sadtler, 2006). Such designs for BoP contexts are frequently termed frugal, 
disruptive, or catalytic innovation, alluding to their lower cost and features but also to their potential to ultimately “disrupt" even ToP markets. In BoP environments, poor people with limited options and income might welcome the opportunity to purchase a product or service that is of basic quality as long as it improves their choices due to its significantly lower price. For instance, before Aravind Eye Care started offering inexpensive cataract surgeries the alternative for a poor person was to remain blind (Rangan \& Thulasiraj, 2007).

Resource limitations do not manifest themselves only as absolute limitations in covering the cost of needed products or services, but also through the relative risk that they represent for BoP clients. Vulnerability is a key issue (Collins et al., 2009; Morduch, 1999); one wrong choice or investment can be highly detrimental to survival. Thus, $\mathrm{BoP}$ consumers tend to be much more risk averse than consumers in more munificent environments. Templates that significantly reduce the real and perceived risk of adopting a new product or service can thus enhance the viability of a template at the BoP (Anderson \& Markides, 2007; Kayser \& Budinich, 2015).

In some instances, credit provision can also reduce the perceived investment risk. For example, Toyola, a BoP venture selling efficient cooking stoves in Ghana, initially gives its product to poor customers for free and instructs them to collect the savings from reduced charcoal consumption for three months - achieving repayment rates of 95\% (Kayser \& Budinich, 2015). Renting out the use of a costly machine or other consumer durable can similarly mitigate the risk for people at the BoP and adapt to the small-scale investments they can afford. In conclusion, integrating into a template a substantial reduction of cost, risk, or both could greatly 
increase its appropriateness for a BoP context, and its ability to achieve the objectives of initial viability and potential scalability at the BoP.

\section{Substitutes for Missing or Poorly Functioning Institutions}

The institutional voids prevalent at the BoP, meanwhile, pose different challenges to the development and replication of templates at the BoP. Khanna and Palepu $(1997,2000)$ have demonstrated that in underdeveloped markets, institutional voids across capital, labor, and product markets as well as government regulation and contract enforcement may favor the development of substitutes for such services in-house. Internalizing the services of missing institutions cost-effectively — or outsourcing them to other organizations, such as local or international NGOs - may increase the viability of a template at the BoP. For instance, a major institutional void that acts as an impediment to successful template development in the $\mathrm{BoP}$ is the lack of consistent registration of people or of their economic activity (Webb et al., 2013, 2009). Organizations at the BoP can nevertheless develop templates that use new, cost-effective technologies as a means of addressing the lack of registration and monitoring, and reducing the associated transaction costs. For instance, microcredit organizations have begun using biometric authentication to register clients, with positive results (Giné, Goldberg, \& Yang, 2012;

Hernandez \& Mugica, 2003). Alternatively, in sub-Saharan Africa, organizations have taken advantage of increasing mobile phone penetration to tie the sales of products and services to clients identified through their mobile accounts.

Social accountability can also mitigate the costs of informality and lack of information regarding individuals' behavior. Microcredit organizations have made a breakthrough by 
developing templates that rely on provision of group loans premised on group repayment and accountability in order to overcome institutional voids (Ghatak, 1999; Stiglitz, 1990; Yunus, 1998). Although lack of collateral and lack of developed registries of past credit history deterred traditional banks from lending to the poor (Yunus, 1998), microfinance organizations managed to leverage family and kinship ties and social group pressure (Khanna \& Palepu, 2000) to ensure timely repayment of loans.

\section{Business Model Versus Technological Innovation}

While many practitioners and scholars expected technological innovation to serve as the basis for creating organizations and markets that could substantially improve the lives of the poor (Hammond, 2001; Schumacher, 2011; Warschauer \& Ames, 2010), templates that succeed in improving conditions for poor people at the BoP need not have an advanced technological product at their core. First, a lack of income is a major limitation (Karnani, 2007; Prahalad \& Hammond, 2002) that often constrains the use of new technologies. Second, as previously mentioned, living at the limits of subsistence, people at the BoP have a limited capacity to deal with uncertainty and risk (Collins et al., 2009), including experimenting with new, unproven technologies that might fail. Third, people at the BoP often do not have the education and adequate exposure to complex technologies needed for a quick learning curve and adoption of emerging technologies. Finally, maintaining complex technological products often requires an infrastructure of service outlets. Due to these often overlooked reasons, templates primarily based on technological innovation have frequently failed to deliver their purported objectives (Acumen, 2011). An example is the One Laptop Per Child project, whose results have failed to 
meet its ambitious objectives (Warschauer \& Ames, 2010). Another example is Project Impact, which successfully developed the technology for a low-cost hearing aid but faced considerable obstacles in bringing it to market (Acumen, 2011).

In contrast, we propose that successful templates at the BoP will focus less on delivering new-to-the-world technological innovation that often implies high costs and possibly high maintenance needs, neither of which can be borne by poor people, and more on business model innovation that overcomes the limitations associated with resource scarcity and institutional voids. Templates based on business model innovation may fare better at the BoP because sufficiently suitable technologies that can deliver value for the poor are typically already available. Organizations such as IDE or Kickstart, which provide irrigation pumps to farmers who previously lacked irrigation options, developed their templates around products based on rudimentary technologies that would hardly be considered to be at the cutting edge of technological innovation in their area. Likewise, M-Pesa in Kenya has been very successful in forming a template that offers easy money transfers through a mobile phone service to BoP customers, even though the software and hardware technology of the phones is far behind the technological innovation frontier. Recent research disentangling upstream innovation (“invention”) from downstream commercialization ("innovation”) in high-technology environments highlights the importance of the latter for successful delivery of new products or services (Kapoor \& Klueter, 2014) in cutting-edge ToP markets. We suggest that the positive effect of downstream business model innovation on template development and replication success is bound to be even more pronounced in challenging BoP contexts. 


\section{Moderately Embedded Entrepreneurs}

A further mechanism that affects template development at the $\mathrm{BoP}$ is related to the hybrid motivation necessary for persistence in challenging BoP environments. Due to the trade-offs between financial and social objectives (Kistruck et al., 2013; London et al., 2010) and the low or modest financial profits typically accruing at the BoP (Ansari et al., 2012; Karnani, 2007), for many big corporations that endorsed the high impact and high profit mantra of the BoP proposition, the reality of BoP operations has been sobering (Hart \& Simanis, 2008).

Large multinational corporations are typically alien to local communities, and thus may be unable to develop relevant products and services (Simanis \& Hart, 2009). That happens even in cases where they adopt the co-creation and ethnographic immersion approaches advocated by many BoP proponents, because creating a market in the absence of one can prove extremely challenging (Simanis, 2011). Companies alien to the local context tend to frame deficiencies as problems to be rectified, leading to negative business concepts and potentially appearing as opportunistic (Arora \& Romijn, 2012; Simanis, 2011). Moreover, they need to overcome substantial barriers to gain the trust of local communities or deal with crime and informality (Anderson et al., 2010; Kistruck et al., 2011). Compounding these challenges, multinational organizations struggle to reconcile their BoP initiatives with their core business models internally (London \& Hart, 2004; Olsen \& Boxenbaum, 2009). Strikingly, even when they manage to overcome these challenges, frequently they eventually abandon the activity, marginalize it, or assign it to their CSR departments. Two examples are the Orja clean cookstove business developed by BP in India and the soy protein business of Solae in the same country, which were 
marginalized due to a management change and a financial downturn respectively (Kayser \& Budinich, 2015; Simanis, 2011).

Some authors have addressed this issue by urging greater embeddedness and commitment on the part of multinational corporations (London \& Hart, 2004; Simanis \& Hart, 2009). Yet embeddedness is not a quality that can be developed quickly. Ironically, the successful examples cited by BoP proponents (Prahalad, 2009; Simanis \& Hart, 2009) are usually NGOs that were embedded in and committed to a local context from the start, such as Grameen and BRAC in Bangladesh. We suggest that during the early stages of template development, organizations that have realistic expectations are more likely to sustain their operations in the face of adversity and limited profits. As a result, entrepreneurs or organizations with an explicit social motivation are more likely to be undeterred by low financial performance as long as social impact is being realized, and therefore more likely to persist in their efforts until a viable template has been developed (Ault \& Spicer, 2014; Kistruck et al., 2013).

Templates with a built-in social orientation and realistic financial projections are frequently developed by individuals or organizations that are highly knowledgeable of and empathetic with a local context (Miller, Grimes, McMullen, \& Vogus, 2012; Rivera-Santos et al., 2015) while retaining a certain outsider perspective (Dorado \& Ventresca, 2013; Martí, Courpasson, \& Dubard Barbosa, 2013). Such actors have additional advantages in terms of template development. First, they are more likely to come up with a relevant solution: "Being grounded in settings of poverty facilitates the appreciation, understanding, and accurate interpretation of what occurs within such settings" (Bruton et al., 2013, p. 684). Second, they naturally enjoy the local 
community's trust and goodwill, which are based on informal ties (Rivera-Santos \& Rufín, 2010). An example is Grameen's repeated success in developing new templates for the BoP, such as Grameen Phone, through leveraging their close ties with the community forged during the development of their microcredit model (Simanis \& Hart, 2009). Thus, an entrepreneur or organization that is embedded in the local BoP context is more likely to be both motivated and capable of developing a viable template for the BoP.

On the other hand, over-embeddedness in the local context can hinder the ability of individuals or organizations to undertake the divergent action that is needed to create social value (Dorado \& Ventresca, 2013; Seelos, Mair, Battilana, \& Dacin, 2011) and to broaden their reach beyond their original site (Ansari et al., 2012; Portes \& Haller, 2005). Consequently, individuals and organizations that balance the insider and outsider perspectives (Haas, 2010; Martí et al., 2013) are more likely to initiate entrepreneurial activities in highly constrained environments. Such actors are better positioned to successfully support novel templates, as they are credible enough to implement them and motivated enough to continue with their efforts even in the face of modest profits or significant challenges (Dorado \& Ventresca, 2013; Seelos et al., 2011). For instance, Mohammad Yunus of Grameen Bank, a local professional with international experience, and Martin Fisher of Kickstart, an international professional who migrated into a local community (Fisher, 2006; Yunus, 1998), are examples of moderately embedded entrepreneurs who are natural candidates for the task of developing templates for the BoP. 


\section{Behavioral Change}

For many organizations active at the BoP, their hybrid motivation and, in particular, the social impact objective of their work may lead them to aspire to effect substantial changes in the behavior of poor people. Yet strong local perceptions - for instance, those related to animal rearing or agricultural farming techniques - are very difficult to influence or replace (Sutter et al., 2014; Thurow, 2013). Moreover, the assumption that poor people do not have strong product or service preferences rooted on local cultural differences has derailed several well-intentioned attempts to market to the BoP, even when products have been very cheap or given for free (Acumen, 2011; Kayser \& Budinich, 2015). For instance, offering mosquito nets, either very cheap or for free, has not ensured their consistent use by poor people (Tarozzi et al., 2014), as many find sleeping under nets uncomfortable, consider malaria a trivial disease, or attribute it to causes other than mosquitoes (Shah, 2011).

Templates can differ in terms of the expectations of behavioral change they require. If substantial behavioral change on the part of customers and employees is a main component of the template to replicate, the rate at which these can replicate under high cultural distance conditions will be significantly lower. Hybrid motivation might encourage efforts to substantially change behavioral patterns of poor people at the BoP, yet organizations should not underestimate the difficulty and time needed to effect these changes. Some companies have succeeded in breaking through strong local preferences by positioning their products or services as status symbols, leveraging the positive power of "negative" mechanisms such as envy and social pressure. For instance, Sanishop has converted affordable toilets into an object of status, with 
simple techniques such as painting the wall behind the toilet they install, so that people will be proud and talk to neighbors about their new possession (Kayser \& Budinich, 2015).

Organizations can also leverage the power of early adopters such as local businesses or wellrespected community members to make their products or services more desirable. Yet in cases where deep inequalities need to be addressed and lasting behavioral change needs to be effected, purely philanthropic interventions rather than financially sustainable BoP templates might be more relevant (Mair et al., 2011), as the time, costs, and risks required for such deep behavioral changes are likely to be substantial, likely exceeding what an economically self-sustaining template would be able to accommodate.

\section{The BoP as Employees}

Due to the resource scarcity present in BoP contexts, coming up with a scalable template for the BoP entails overcoming demand-side as well as supply-side limitations. Offering opportunities for local people to gain income is often a critical component of successful BoP templates (Fisher, 2006; London et al., 2010), and organizations that incorporate local people into the value chain as employees are more likely to overcome the limitations of restricted income (Anderson et al., 2010). Synergies can be achieved when locals earn wages acting as agents or entrepreneurs for an organization operating in the BoP (Kistruck, Sutter, et al., 2012; Kistruck, Webb, et al., 2011; Van Kirk, 2010), part of which can be spent on buying products and services offered by the organization. Moreover, poor people can be mistrustful of new products or services; as a result, their endorsement by trusted community members greatly reduces the barriers to adoption (Kayser \& Budinich, 2015; Thurow, 2013). 
Engaging people within the value chain is also in line with the hybrid motivations needed for success at the BoP. Organizations such as social intermediaries, whose objectives are to improve "transaction arrangements, and to redistribute the resulting economic rents in a more equitable manner," are intent on developing local capability to empower local people (Kistruck et al., 2013, p. 32). Approaches that consider the poor exclusively as consumers have been criticized as inadequate for reducing poverty and improving living standards in both theory and practice (Arora \& Romijn, 2012; Bruton et al., 2013; London et al., 2010). When locals are treated as entrepreneurs or salespeople who own the products they sell, they experience greater pride and identification in their role (Kistruck et al., 2012) and are more aligned with the organization's goals. They can also help organizations create products that are relevant to their needs and perspective (Hart \& Simanis, 2008) and that enjoy their trust and protection (Anderson et al., 2010; London \& Hart, 2004).

Simanis (2011) went as far as to suggest that people at the BoP should be integrated into all stages of the process of template development, through co-creation. However, there can be challenges when pursuing co-creation at all stages of template development. Building local capacity can sometimes be more time-consuming and less efficient than if the organization were to leverage its existing capabilities or personnel to perform certain tasks (Bhatti \& Ventresca, 2012; Kistruck et al., 2013). Furthermore, the interest of locals engaged as part-time salespeople might wane as they progressively saturate their proximate geographic territory (Kayser \& Budinich, 2015; Van Kirk, 2010). Moreover, poverty engenders a lack of empowerment (Sen, 1999), and know-how can be limited under such circumstances (Sutter et al., 2014). It is 
therefore hard to imagine people living at the border of poverty coming up with templates for the provision of goods and services such as microcredit, irrigation pumps, or cataract surgeries. Indeed, the local entrepreneurs who came up with those models were rarely living in abject poverty themselves. Van Kirk (2010), for instance, described how local weavers in Guatemala could not understand that the solution to their loss of ability to distinguish the threads they were weaving could be a simple pair of corrective glasses, nor did local women believe him when he told them they could be trained to provide such glasses to those needing them - they thought that such activities could only be conducted by educated "doctors." Yet, once the solutions are explained to local people and they are trained and empowered to gradually take on the relevant duties, they can be extremely successful in those tasks (Van Kirk, 2010).

Templates that fare best typically break down the involvement of local people into concrete, easily understandable stages that can be replicated across locations with limited variation. For instance, SKS microfinance has been involving locals who follow easy procedures as microcredit officers, achieving strikingly fast replication of their template (Akula, 2008). Similarly, BRAC in Bangladesh offers certain products, such as eyeglasses, to poor clients through a system of village ladies. The organization has consciously decided to opt for a very simple offering in those cases; it seems extremely constraining to Westerners, but it allows even illiterate women to perform sales following easily understandable instructions (Kayser \& Budinich, 2015). We thus suggest that inclusion of local people as employees or producers into BoP templates (Ansari et al., 2012; Hall, Matos, Sheehan, \& Silvestre, 2012) is a mechanism that can enhance the initial 
viability and large-scale replication potential, but only if such involvement has been standardized into a simple template.

\section{TEMPLATE REPLICATION AT THE BOP}

We now turn to mechanisms that may directly affect the ability of an organization to successfully replicate a template at scale at the BoP once developed. Large-scale template replication is possible after the development of an initial successful template has taken place (Winter \& Szulanski, 2001). As in the case of template development, template replication will be affected by the distinctive conditions that characterize the BoP, namely resource scarcity, institutional voids, and hybrid motivation.

\section{Visibility and Claims to the Organization}

Even if a template is successful in the location where it was originally developed, in a severely constrained environment success itself can become a liability and an impediment to its replication in new locations. In resource-abundant ToP environments, the initial success of a template attracts further resources from interested audiences that stand to benefit from it (Aldrich \& Fiol, 1994; Pontikes, 2012), but the same is not automatically true in resource-constrained BoP environments. Any activity that generates even modest revenue or earnings may be evaluated as highly successful in environments of abject poverty. In these environments, the more an organization grows, the more its founder(s) will be faced with increasing demands and claims from rent-seeking constituencies to share the profits or financially help those in need (De Castro, Khavul, \& Bruton, 2014; Thompson \& MacMillan, 2010). Outsiders might be unable to distinguish between activity levels, revenue levels, and the resulting profits or losses that accrue 
to a new organization (Thompson \& MacMillan, 2010). For example, local audiences might equate highly visible activities with evidence of high profitability. Thus, demands for contributions from stakeholders and other outsiders can negatively affect the growth of a new organization that still lacks sufficient scale and slack (Kistruck, Webb, Sutter, \& Bailey, 2014; Sutter et al., 2013; Thompson \& MacMillan, 2010). Indeed, De Castro et al.'s extensive qualitative investigation $(2014$, p. 88$)$ indicated that "to avoid a backlash from those on whom their success depended, entrepreneurs took measures to minimize visible symbols of success." Additionally, Sutter and colleagues (2013) found that illegitimate individuals or organizations imposed illegal financial demands on new organizations when they were successful and visible in their communities. In response, entrepreneurs operating in $\mathrm{BoP}$ environments resorted to "altering their business model in a way that decreased exposure to illegitimate actors, working without publicity, disguising the nature or existence of the business, and moving the business to a new location where the illegitimate actors could not find them" (Sutter et al., 2013, p. 744).

Conversely, there are certainly examples of higher visibility ultimately generating benefits for the replication of BoP templates. For example, Husk Power Systems' ability to prove the success of its original template helped it secure the support of the Indian government for the replication of its model to a number of other Indian provinces. In Kenya EABL managed to achieve a $100 \%$ excise tax rebate due to the health and safety benefits of its low-priced "Senator Special" beer, in contrast with the illicit, and often highly toxic, brews it was competing with (Kayser \& Budinich, 2015). Thus, extending the argument of Kistruck et al. (2014) that formalization is a double-edged sword that can augment both resource provision and resource 
appropriation, we concur that visibility of the activity might have adverse effects on growth at the early stages of template replication, yet positive effects at later stages.

In addition, providing a rationale for operation that is premised on substantial social value creation might be able to shield the fledgling organization from value appropriation claims, as local communities and stakeholders are more likely to forgo financial benefits in the case of highly visible social benefits. One example of this mechanism is provided by Thompson and MacMillan (2010), who cited a project aiming to create bakeries that would provide employment opportunities to distressed areas of South Africa: Local elders who saw increased activity assumed that the organization was realizing large profits and demanded a correspondingly large fee. To counter these demands, which could have been fatal for the project, the entrepreneur and employees had to spend considerable time explaining the objectives and social benefits that would follow for their region.

\section{Infrastructure Building}

It is important to recognize that the success of template replication sometimes depends on mechanisms that are largely outside the sphere of influence of the organization itself. For instance, it would be very hard for small-scale organizations to lobby governments for institutional changes, as their small size precludes them from exerting significant power or pressure. Their efforts at influencing institutions can constitute a big burden in terms of money and time, potentially leading to their demise (Tracey, Phillips, \& Jarvis, 2011). Furthermore, even when a number of ventures and other stakeholders collectively realize the need to collaborate in order to develop a market and change the institutional voids that inhibit it, 
collaboration frequently breaks down due to a "tragedy of the commons" (Kayser \& Budinich, 2015). A tragedy of the commons can arise when mutual benefits are expected from collaboration but no single actor wants to be the first to contribute the substantial upfront investments and efforts, as they fear that other actors will subsequently free-ride and benefit without incurring any costs (Kayser \& Budinich, 2015; Ozcan \& Santos, 2014).

However, if the market to be created has a strong social value component, interested nonprofit organizations or foundations may sometimes volunteer to bear the high cost and substantial effort of changing institutional structures. For instance, USAID and other development agencies have been investing for years in infrastructure building to enable the microcredit industry to eventually become financially viable (Rhyne, 2001). They have lobbied governments to create the regulatory frameworks that enable nonprofits to act as financial institutions while also helping to raise funds for the financing of microcredit institutions. More recently, the AGRA Foundation, set up by international donors, has been investing in infrastructure and R\&D to improve the viability of agricultural BoP templates in Africa (Bell \& Milder, 2008; Thurow, 2013). It intervenes at various stages of the value chain where collective institution building has failed, such as those related to scientific training, crop research, seed bulking, and seed distribution. In general, once such costs and efforts at infrastructure building are assumed by external organizations, the replication of a BoP template becomes more feasible as infrastructure costs need not be borne by the focal organization alone — or passed on to its customers and beneficiaries. 


\section{Leverage by Influential External Organizations}

Finally, we wish to highlight an important paradox that affects the replication of successful BoP templates. While moderately embedded entrepreneurs or organizations will be the ones most motivated to persist in their search for viable templates, those entrepreneurs frequently lack the motivation or skills to replicate such templates at scale and realize their full social and economic impact potential (George et al., 2012). Even in ToP markets, entrepreneurs tend to be attached to their organizations, and they cannot easily cede control and develop organizational structures so that the business progresses naturally through its life cycle (Greiner, 1972). The founder syndrome is similarly pervasive in BoP contexts, and even more so due to the hybrid motivation sustaining the efforts of many founders (Kayser \& Budinich, 2015). Founders who have established their organizations due to prosocial motivations (Miller et al., 2012) are more likely to be intimately connected to them and unwilling to let go, and they may have fewer options for exiting their programs without destroying social value (Kayser \& Budinich, 2015). Additionally, many — though not all—founders of BoP organizations tend to adopt a "small is beautiful" mindset (Schumacher, 2011), believing that scale will greatly decrease the quality of their offering, as organizational structure and bureaucracy could mitigate the personal attention and commitment that can be channeled to each project and beneficiary (Kayser \& Budinich, 2015). The motivation of founders to pursue replication typically is also affected by a perceived lack of resources for effecting a large-scale replication of their templates.

When an entrepreneur has already developed a viable template, larger organizations can step in and leverage their resources to help replicate it faster. While larger organizations can be 
active, as previously mentioned, in influencing the institutional environment that can enable successful template replication, their undeniable resources also make them suitable candidates for directly leveraging templates (George et al., 2012); indeed, they sometimes manage to partner with local organizations to offer greater scale. Examples can be found in the cases of large multinationals such as Nortel and Danone, who, through their collaborations with local organizations, have scaled up telecommunications services and nutritious foods respectively for Bangladeshi people (Seelos \& Mair, 2007), or in international and national NGOs and foundations that have partnered with BRAC to replicate its successful templates outside its home country of Bangladesh in Asian, African, and Middle Eastern countries (Davis, 2013, 2015).

Similarly, governments, with their mandate to provide better economic and human development to their constituencies, can be an alternative facilitator of replication. Scarce research exists that examines such replication, but programs that have a proven template have sometimes managed to successfully lobby governments to secure contracts that can ensure their large-scale replication. Ziqitza Health Care, which was the first organization to establish an affordable ambulance service in Mumbai at a time when suitable ambulance services for the public were almost nonexistent, is a fitting example. The organization managed to successfully lobby the government for transparent procurement and for recognition of the social benefits of its template; as of 2011 it was offering a combination of 199 subsidized and of 42 user-paid services across various Indian states (Batavia, Chakma, Masum, \& Singer, 2011). Figure 1 summarizes the relevant mechanisms identified as facilitating the development and replication of templates at the BoP, linked to the distinctive conditions of BoP environments. 


\section{Figure 1}

\section{Determinants of Successful Template Development and Replication at the BoP}

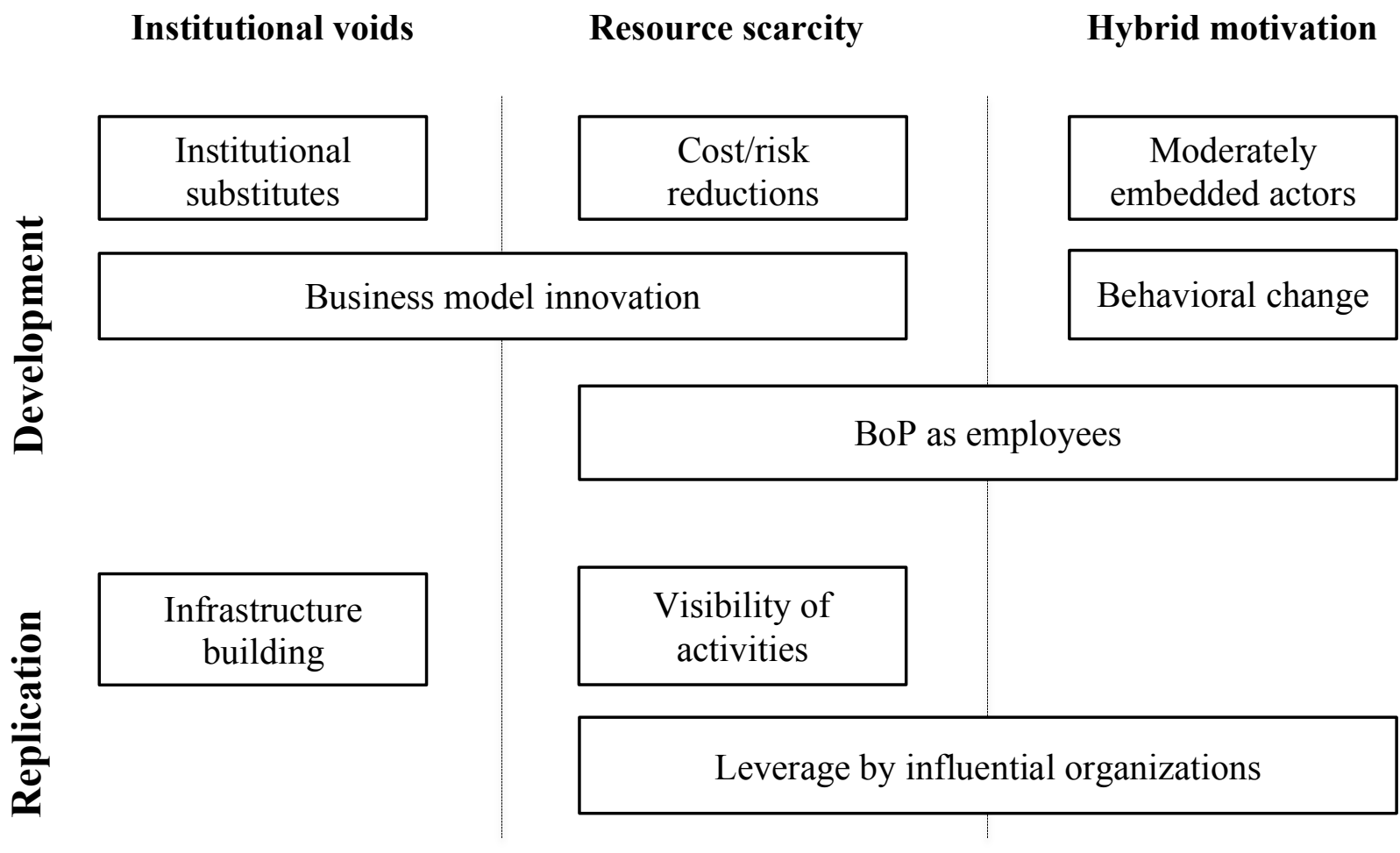

\section{DISCUSSION AND CONCLUSIONS}

This paper examines the distinctive mechanisms affecting the development and replication of templates within BoP contexts, a subject that has generated great interest but whose development of theoretical guidance has lagged behind press "hype" and anecdotal evidence (Kistruck et al., 2012; Kolk et al., 2014; London \& Hart, 2004). By integrating insights from the emerging 
literature on the conditions present in BoP markets and the specific challenges to the development and growth of organizations at the BoP (Kistruck et al., 2013; Kistruck et al., 2012; London \& Hart, 2004) with extant literature on the replication of organizational routines and templates in ToP contexts (Szulanski \& Jensen, 2006; Winter \& Szulanski, 2001; Winter et al., 2012), we identify distinctive conditions at the BoP and develop a framework for the determinants of successful development and replication of templates there.

\section{Contributions and Implications}

This article contributes to the BoP literature (e.g., Kistruck et al., 2012; Kolk et al., 2014; London \& Hart, 2004; Seelos \& Mair, 2007) and the literature on the replication of organizational routines and templates (D’Adderio, 2014; Jonsson \& Foss, 2011; Winter \& Szulanski, 2001; Winter et al., 2012) by advancing our understanding of the potential of developing and replicating organizational templates to promote social and economic development in these challenging environments. The more mature literature on the replication of organizational routines and templates at the ToP offers a body of theory and findings that can greatly inform research on the BoP, specifically research on the large-scale replication of templates there, because the debate on local adaptation versus replication at the BoP (Hart \& Simanis, 2008; Kistruck et al., 2011; Sutter et al., 2014) is inherently closely related to the corresponding debate in the literature on replication at the ToP (D'Adderio, 2014; Ringov et al., 2016; Winter \& Szulanski, 2001). Our key premise, based on observations from research and practice and consistent with extant theory developed for the ToP (Winter \& Szulanski, 2001; Winter et al., 2012), is that developing and leveraging templates that are economically viable and 
replicable can fundamentally magnify the economic and social impact of organizations active at the BoP.

Our synthesis of extant BoP literature suggests that a number of conditions present at the BoP — key among them resource scarcity, institutional voids, and hybrid motivation (Battilana \& Dorado, 2010; Mair et al., 2011; Seelos \& Mair, 2007)—render template development and replication more elusive than at the ToP. At the development phase, templates will need to incorporate resilience and robustness to the above conditions, which are likely to be endemic across BoP environments. By clarifying these basic premises, this article attempts to bring greater cohesiveness to the highly fragmented BoP debate and literature (Kolk et al., 2014) and thereby facilitate future cumulative progress. Taking that as our point of departure, we propose mechanisms that facilitate the development and large-scale replication of templates at the BoP, providing an organizing framework that can be used as a point of departure and further elaborated in future research.

We make a theoretical distinction between mechanisms that affect the development of templates at the BoP versus mechanisms that affect the replication of those templates. Moreover, we examine the distinctive mechanisms affecting the where, how, and what of successful template development and replication (Winter \& Szulanski, 2001; Winter et al., 2012) in the specific context of BoP environments, given their distinctive conditions. These mechanisms can attenuate the distinctive conditions of the BoP and facilitate the development and replication of templates at the BoP. We suggest that what can be successfully replicated to large scale are templates that are standardized and developed with an eye toward major cost and risk reductions, 
business model innovation, low-cost substitutes for key missing institutions, and active engagement of BoP communities as employees or producers, while avoiding the pursuit of major behavioral changes. As far as how, we contend that organizations can leverage social mechanisms to make products highly desirable when behavioral change is necessary, and they can grow under the radar until the point that their visibility is inevitable; after that they need to exhibit clear social benefits to communities and get endorsement for their model from highly influential organizations at the local and national levels. Finally, the necessity to offer culturally appropriate products and services suggests that the where of replication may bear similarities to ToP markets (Jonsson \& Foss, 2011): Behavioral change difficulties are less likely to be pronounced in settings with similar cultural idiosyncrasies, and so expanding to areas of close geographical or cultural proximity can enable large-scale replication with less extensive adaptation.

To the above dimensions we add the who of successful large-scale replication. Countering the underlying assumption in the literature that any organization can be successful in the $\mathrm{BoP}$ (Hart \& Simanis, 2008; Prahalad, 2009; Prahalad \& Hammond, 2002), we suggest that the complex distinctive characteristics of these contexts make the question of who particularly critical for success. We theorize that moderately embedded individuals or organizations, such as local entrepreneurs with international exposure — or alternatively expatriates with long-term residence in their host country—are the ones better positioned and most motivated for successful template development (Dorado \& Ventresca, 2013; Martí et al., 2013; Miller et al., 2012). While these same entrepreneurs or organizations could also be successful at the replication stage, it is 
more likely that, for a variety of reasons we discussed, replication will likely be facilitated by the leverage of external powerful organizations or actors, such as large local companies, governments, NGOs, or international social business groups.

Thus, bridging the BoP and the replication of templates literatures results in a number of contributions and implications for the latter too. While this literature has a longer history with well-established premises and increasingly more nuanced theoretical development (Jonsson \& Foss, 2011; Ringov et al., 2016; Winter \& Szulanski, 2001), it has generally focused theoretical and empirical attention on countries and populations at the ToP (for exceptions see Kistruck et al., 2011; Sutter et al., 2014). We extend the boundaries of this literature to the BoP context by suggesting specific mechanisms, not present in current replication literature focused on the ToP, that affect template development and replication at the BoP. Thus, this study can be viewed as advancing a more nuanced view of the challenge of replication that makes a step toward extending the boundaries of replication research not only beyond the ToP, but toward the very challenging context of the BoP where approximately 1 billion of the world's population live.

\section{Limitations and Future Research}

This study can be viewed as a step toward the greater integration of the BoP and replication literatures. Our discussion of mechanisms that influence replication at the BoP is not meant to be exhaustive, but rather focuses on those mechanisms that could be considered particularly relevant and salient in extant research on the BoP. We have thus centered our discussion on those mechanisms that are closely linked to the key distinctive conditions of the BoP; other 
mechanisms might affect the replicability of templates across both $\mathrm{BoP}$ and $\mathrm{ToP}$ environments, yet these lie outside the scope of this article.

We believe that the perspective and framework on the determinants of successful development and large-scale replication of $\mathrm{BoP}$ templates provided by this study open up a number of fruitful avenues for future research. Specifically, researchers interested in the development and replication of scalable solutions at the BoP could theoretically and empirically examine the mechanisms advanced in this article. For example, scholars could examine and further refine the effect that characteristics of the focal organization, such as local embeddedness or type of motivation, have on the success of the template's development and replication. Furthermore, qualitative work could shed further light on the processes underlying the mechanisms we identify, which are only partly understood. For instance, the relationship between behavioral change requirements and template viability at the BoP could be unpacked further, and the same holds for the process through which organizations build the appropriate infrastructure for template replication at the BoP. We therefore see substantial promise in both large-sample empirical examinations of the mechanisms identified in this article and their further theoretical exploration and refinement. Future studies could also shed light on additional mechanisms not identified here that might also influence template development and replication at the BoP.

Future work could also explore whether and to what extent some of the factors that affect the development and replication of templates at the BoP also apply to the development and replication of templates at the ToP. For example, major cost reductions might be particularly 
relevant to the replication of templates even at the ToP, as notable "disruptive" templates, such as low-cost airlines, IKEA furniture, and cheap clothing stores have indicated. Similarly, integration of local people as both buyers and employees in templates could be adopted at the ToP, and might hold certain potential as poverty now afflicts many communities in otherwise developed countries. In conclusion, we consider the subject of large-scale template replication at the BoP ripe for greater input, debate, and scrutiny by both BoP scholars and scholars studying the development and replication of organizational routines and templates, and we look forward to a stimulating stream of future integrative, boundary-spanning research in this highly consequential field of inquiry. 


\section{REFERENCES}

Acumen. (2011). 10 things we've learned about tackling global poverty. Author: New York. Retrieved from http://acumen.org/wp-content/uploads/2013/03/10-Things-Weve-LearnedAbout-Tackling-Global-Poverty.pdf

Akula, V. (2008). Business basics at the base of the pyramid. Harvard Business Review, 86(6), $53-57$.

Aldrich, H. E., \& Fiol, C. M. (1994). Fools rush in? The institutional context of industry creation. Academy of Management Review, 19(4), 645-670.

Anderson, J. L., \& Markides, C. (2007). Strategic innovation at the base of the pyramid. MIT Sloan Management Review, 49(1), 83-88.

Anderson, J. L., Markides, C., \& Kupp, M. (2010). The last frontier: Market creation in conflict zones, deep rural areas, and urban slums. California Management Review, 52(4), 6-28.

Anokhin, S., \& Schulze, W. S. (2009). Entrepreneurship, innovation, and corruption. Journal of Business Venturing, 24(5), 465-476.

Ansari, S. M., Munir, K., \& Gregg, T. (2012). Impact at the "bottom of the pyramid": The role of social capital in capability development and community empowerment. Journal of Management Studies, 49(4), 813-842.

Ansari, S. M., \& Zajac, E. J. (2010). Made to fit: How practices vary as they diffuse. Academy of Management Review, 35(1), 67-92.

Arora, S., \& Romijn, H. (2012). The empty rhetoric of poverty reduction at the base of the pyramid. Organization, 19(4), 481-505. 
Ault, J. K., \& Spicer, A. (2014). The institutional context of poverty: State fragility as a predictor of cross-national variation in commercial microfinance lending. Strategic Management Journal, 35(12), 1818-1838.

Austin, J., Stevenson, H., \& Wei-Skillern, J. (2006). Social and commercial entrepreneurship: Same, different, or both? Entrepreneurship Theory and Practice, 30(1), 1-22.

Bartlett, C. A., \& Ghoshal, S. (1999). Managing across borders: The transnational solution (Vol. 2). Philadelphia: Taylor \& Francis.

Batavia, H., Chakma, J., Masum, H., \& Singer, P. (2011). Market minded development. Stanford Social Innovation Review, 9(1), 66-71.

Battilana, J., \& Dorado, S. (2010). Building sustainable hybrid organizations: The case of commercial microfinance organizations. Academy of Management Journal, 53(6), 14191440.

Battilana, J., Sengul, M., Pache, A.-C., \& Model, J. (2015). Harnessing productive tensions in hybrid organizations : The case of work integration social enterprises. Academy of Management Journal, 58(6), 1658-1685.

Bell, D. E., \& Milder, B. (2008). Alliance for a green revolution in Africa (AGRA). Cambridge, MA: Harvard Business Publishing.

Bhatti, Y. A., \& Ventresca, M. (2012). The emerging market for frugal innovation: Fad, fashion, or fit? Available at SSRN : http://ssrn.com/abstract52005983

Bhatti, Y. A., \& Ventresca, M. (2013). How can “frugal innovation” be conceptualized? Available at SSRN: http:// papers.ssrn.com/sol3/papers.cfm?abstract_id52203552 
Bruton, G. D., Ketchen, D. J., \& Ireland, R. D. (2013). Entrepreneurship as a solution to poverty. Journal of Business Venturing, 28(6), 683-689.

Christensen, C. M., Baumann, H., Ruggles, R., \& Sadtler, T. M. (2006). Disruptive innovation for social change. Harvard Business Review, 84(12), 94-98.

Collins, D., Morduch, J., Rutherford, S., \& Ruthven, O. (2009). Portfolios of the poor: How the world's poor live on $\$ 2$ a day. Princeton, NJ: Princeton University Press.

Cull, R., \& Morduch, J. (2007). Financial performance and outreach: A global analysis of leading microbanks. Economic Journal, 117(517), F107-F133.

D’Adderio, L. (2014). The replication dilemma unravelled: How organizations enact multiple goals in routine transfer. Organization Science, 25(5), 1325-1350.

Davis, S. (2013). Scaling up without losing your edge. Harvard Business Review. Retrieved from https://hbr.org/2013/01/for-social-enterprises-size-ma

Davis, S. (2015). An approach to ending poverty that works. Harvard Business Review. Retrieved from https://hbr.org/2015/01/an-approach-to-ending-poverty-that-works

de Carvalho, A., Klarsfeld, L., \& Lepicard, F. (2012). Leveraging information and communication technology for the base of the pyramid. Paris: Hystra.

De Castro, J. O., Khavul, S., \& Bruton, G. D. (2014). Shades of grey: How do informal firms navigate between macro and meso institutional environments? Strategic Entrepreneurship Journal, 8(1), 75-94.

Dees, J. G., Anderson, B. B., \& Wei-Skillern, J. (2004). Scaling social impact. Stanford Social 
Innovation Review, 1(4), 24-33.

De Soto, H. (2003). The mystery of capital: Why capitalism triumphs in the West and fails everywhere else. New York: Basic Books.

Devinney, T., Midgley, D., \& Venaik, S. (2000). The optimal performance of the global firm: Formalizing and extending the integration-responsiveness framework. Organization Science, 11(6), 674-695.

Dorado, S., \& Ventresca, M. J. (2013). Crescive entrepreneurship in complex social problems: Institutional conditions for entrepreneurial engagement. Journal of Business Venturing, 28(1), 69-82.

Fisher, M. (2006). Income is development: Kickstart's pumps help Kenyan farmers transition to a cash economy. Innovations, 1(1), 9-30.

Friedman, M. (2009). Capitalism and freedom. Chicago: University of Chicago Press.

George, G., McGahan, A. M., \& Prabhu, J. (2012). Innovation for inclusive growth: Towards a theoretical framework and a research agenda. Journal of Management Studies, 49(4), 661683.

Ghatak, M. (1999). Group lending, local information and peer selection. Journal of Development Economics, 60(1), 27-50.

Giné, X., Goldberg, J., \& Yang, D. (2012). Credit market consequences of improved personal identification: Field experimental evidence from Malawi. American Economic Review, 102(6), 2923-2954.

Greiner, L. E. (1972). Evolution and revolution as organizations grow. Harvard Business 
Review, 76(3), 55-68.

Haas, M. R. (2010). The double-edged swords of autonomy and external knowledge: Analyzing team effectiveness in a multinational organization. Academy of Management Journal, 53(5), 989-1008.

Hall, J., Matos, S., Sheehan, L., \& Silvestre, B. (2012). Entrepreneurship and innovation at the base of the pyramid: A recipe for inclusive growth or social exclusion? Journal of Management Studies, 49(4), 785-812.

Hammond, A. L. (2001). Digitally empowered development. Foreign Affairs. Retrieved from https://www.foreignaffairs.com/articles/2001-03-01/digitally-empowered-development

Hart, S. L., \& Sharma, S. (2004). Engaging fringe stakeholders for competitive imagination. Academy of Management Executive, 18(1), 7-18.

Hart, S., \& Simanis, E. (2008). The base of the pyramid protocol: Toward next-generation BoP strategy. Ithaca, NY: Cornell University. Retrieved from http://www.stuartlhart.com/sites/stuartlhart.com/ files/BoPProtocol2ndEdition2008_0.pdf

Helfat, C. E., Finkelstein, S., Mitchell, W., Peteraf, M., Singh, H., Teece, D., \& Winter, S. G. (2009). Dynamic capabilities: Understanding strategic change in organizations. Hoboken, NJ: John Wiley \& Sons.

Hermes, N., Lensink, R., \& Meesters, A. (2011). Outreach and efficiency of microfinance institutions. World Development, 39(6), 938-948.

Hernandez, R., \& Mugica, Y. (2003). What works: Prodem FFP's multilingual smart ATMs for micro finance. Washington, DC: World Resources Institute. 
Jensen, R. J., \& Szulanski, G. (2007). Template use and the effectiveness of knowledge transfer. Management Science, 53(11), 1716-1730.

Jonsson, A., \& Foss, N. J. (2011). International expansion through flexible replication: Learning from the internationalization experience of IKEA. Journal of International Business Studies, 42(9), 1079-1102.

Kapoor, R., \& Klueter, T. (2014). Decoding the adaptability-rigidity puzzle: Evidence from pharmaceutical incumbents' pursuit of gene therapy and monoclonal antibodies. Academy of Management Journal, 58(4), 1180-1207.

Karnani, A. (2007). The mirage of marketing to the bottom of the pyramid: How the private sector can help alleviate poverty. California Management Review, 49(4), 90-111.

Kayser, O., \& Budinich, M. V. (2015). Scaling up business solutions to social problems: A practical guide for social and corporate entrepreneurs. Basingstoke, UK: Palgrave Macmillan.

Khanna, T., \& Palepu, K. (1997). Why focused strategies may be wrong for emerging markets. Harvard Business Review, 75, 41-54.

Khanna, T., \& Palepu, K. (2000). The future of business groups in emerging markets: Long-run evidence from Chile. Academy of Management Journal, 43(3), 268-285.

Kistruck, G. M., Beamish, P. W., Qureshi, I., \& Sutter, C. J. (2013). Social intermediation in base of the pyramid markets. Journal of Management Studies, 50(1), 31-66.

Kistruck, G. M., Sutter, C. J., Lount, R., \& Smith, B. (2012). Mitigating principal-agent problems in base-of-the-pyramid markets: An identity spillover perspective. Academy of 
Management Journal, 56(3), 659-682.

Kistruck, G. M., Webb, J. W., Sutter, C. J., \& Bailey, A. V. G. (2014). The double-edged sword of legitimacy in base-of-the-pyramid markets. Journal of Business Venturing, 30(3), 436451.

Kistruck, G. M., Webb, J. W., Sutter, C. J., \& Ireland, R. D. (2011). Microfranchising in base of the pyramid markets: Institutional challenges and adaptations to the franchise model. Entrepreneurship Theory and Practice, 35(3), 503-531.

Kolk, A., Rivera-Santos, M., \& Rufín, C. (2014). Reviewing a decade of research on the "base/bottom of the pyramid" (BOP) concept. Business \& Society, 53(3), 338-377.

Kostova, T., \& Roth, K. (2002). Adoption of an organizational practice by subsidiaries of multinational corporations: Institutional and relational effects. Academy of Management Journal, 45(1), 215-233.

Kotler, P., \& Armstrong, G. (2010). Principles of marketing. Upper Saddle River, NJ: Pearson Education.

Lawrence, P. R., \& Lorsch, J. W. (1967). Differentiation and integration in complex organizations on JSTOR. Administrative Science Quarterly, 12(1), 1-47.

London, T., Anupindi, R., \& Sheth, S. (2010). Creating mutual value: Lessons learned from ventures serving base of the pyramid producers. Journal of Business Research, 63(6), 582594.

London, T., \& Hart, S. L. (2004). Reinventing strategies for emerging markets: Beyond the transnational model. Journal of International Business Studies, 35(5), 350-370. 
Mair, J., \& Martí, I. (2006). Social entrepreneurship research: A source of explanation, prediction, and delight. Journal of World Business, 41(1), 36-44.

Mair, J., \& Martí, I. (2009). Entrepreneurship in and around institutional voids: A case study from Bangladesh. Journal of Business Venturing, 24(5), 419-435.

Mair, J., Martí, I., \& Ventresca, M. (2011). Building inclusive markets in rural Bangladesh: How intermediaries work institutional voids. Academy of Management Journal, 54(4), 819-850.

March, J. G. (1991). Exploration and exploitation in organizational learning. Organization Science, 2(1), 71-87.

Martí, I., Courpasson, D., \& Dubard Barbosa, S. (2013). "Living in the fishbowl.” Generating an entrepreneurial culture in a local community in Argentina. Journal of Business Venturing, 28(1), 10-29.

Miller, T., Grimes, M., McMullen, J., \& Vogus, T. (2012). Venturing for others with heart and head: How compassion encourages social entrepreneurship. Academy of Management Review, 37(4), 616-640.

Morduch, J. (1999). The microfinance promise. Journal of Economic Literature, 37(4), 15691614.

Olsen, M., \& Boxenbaum, E. (2009). Bottom-of-the-pyramid: Organizational barriers to implementation. California Management Review, 51(4), 100-125.

Ozcan, P., \& Santos, F. M. (2014). The market that never was: Turf wars and failed alliances in mobile payments. Strategic Management Journal, 36(10), 1486-1512.

Peteraf, M. A. (1993). The cornerstones of competitive advantage: A resource-based view. 
Strategic Management Journal, 14(3), 179-191.

Pontikes, E. G. (2012). Two sides of the same coin: How ambiguous classification affects multiple audiences' evaluations. Administrative Science Quarterly, 57(1), 81-118.

Portes, A., \& Haller, W. (2005). The informal economy. In N. J. Smelser \& R. Swedberg (Eds.), The handbook of economic sociology (pp. 403-425). Princeton, NJ: Princeton University Press.

Prahalad, C. K. (2009). The fortune at the bottom of the pyramid, revised and updated 5th anniversary edition: Eradicating poverty through profits. Upper Saddle River, NJ: Pearson.

Prahalad, C. K., \& Hammond, A. (2002). Serving the world's poor, profitably. Harvard Business Review, 80(9), 48-59.

Rangan, V. K., \& Thulasiraj, R. D. (2007). Making sight affordable. Innovations case narrative: The Aravind Eye Care System. Innovations, 2(4), 35-49.

Rhyne, E. (2001). Mainstreaming microfinance: How lending to the poor began, grew, and came of age in Bolivia. Bloomfield, CT: Kumarian Press.

Ringov, D., Liu, H., Jensen, R. J., \& Szulanski, G. (2016, September). Replication and augmentation: A reexamination of the replication dilemma. Paper presented at the Strategic Management Society, Berlin, Germany.

Rivera-Santos, M., Holt, D., Littlewood, D., \& Kolk, A. (2015). Social entrepreneurship in subSaharan Africa. Academy of Management Perspectives, 29(1), 72-91.

Rivera-Santos, M., \& Rufín, C. (2010). Global village vs. small town: Understanding networks at the base of the pyramid. International Business Review, 19(2), 126-139. 
Rosenberg, T. (2013, January 16). A hospital network with a vision. New York Times. Retrieved from http://opinionator.blogs.nytimes.com/2013/01/16/in-india-leading-a-hospitalfranchise-with-vision/?_r=0

Schumacher, E. F. (2011). Small is beautiful: A study of economics as if people mattered. New York: HarperCollins Publishers.

Schuster, T., \& Holtbrügge, D. (2014). Resource dependency, innovative strategies, and firm performance in BOP markets. Journal of Product Innovation Management, 31(S1), 4359.

Seelos, C., \& Mair, J. (2007). Profitable business models and market creation in the context of deep poverty: A strategic view. Academy of Management Perspectives, 21(4), 49-63.

Seelos, C., Mair, J., Battilana, J., \& Dacin, M. T. (2011). The embeddedness of social entrepreneurship: Understanding variation across local communities. Research in the Sociology of Organizations, 33, 333-363.

Sen, A. (1999). Development as freedom. Oxford, UK: Oxford University Press.

Shah, S. (2011). The fever: How malaria has ruled humankind for 500,000 years. New York: Farrar, Straus and Giroux.

Simanis, E. (2011). Needs, needs, everywhere, but not a BoP market to tap. In T. London \& S. L. Hart (Eds.), Next generation business strategies for the base of the pyramid: New approaches for building mutual value (pp. 103-126). Upper Saddle River, NJ: FT Press.

Simanis, E., \& Hart, S. (2009). Innovation from the inside out. MIT Sloan Management Review, $50(4), 77$. 
Starr, K. (2014). Getting beyond the hype: Four questions to predict real impact. Stanford Social Innovation Review. Retrieved from http://ssir.org/articles/entry/getting_beyond_hype_four_questions_to_predict_real_impact Stiglitz, J. E. (1990). Peer monitoring and credit markets. World Bank Economic Review, 4(3), $351-366$.

Sutter, C. J., Kistruck, G. M., \& Morris, S. (2014). Adaptations to knowledge templates in baseof-the-pyramid markets: The role of social interaction. Strategic Entrepreneurship Journal, 8(4), 303-320.

Sutter, C. J., Webb, J. W., Kistruck, G. M., \& Bailey, A. V. G. (2013). Entrepreneurs' responses to semi-formal illegitimate institutional arrangements. Journal of Business Venturing, 28(6), 743-758.

Szulanski, G., \& Jensen, R. J. (2006). Presumptive adaptation and the effectiveness of knowledge transfer. Strategic Management Journal, 27(10), 937-957.

Tarozzi, A., Mahajan, A., Blackburn, B., Kopf, D., Krishnan, L., \& Yoong, J. (2014). Microloans, insecticide-treated bed nets, and malaria: Evidence from a randomized controlled trial in Orissa, India. American Economic Review, 104(7), 1909-1941.

Thompson, J. D., \& MacMillan, I. C. (2010). Making social ventures work. Harvard Business Review, 88(9), 66-73.

Thurow, R. (2013). The last hunger season: A year in an African farm community on the brink of change. New York: PublicAffairs.

Tracey, P., Phillips, N., \& Jarvis, O. (2011). Bridging institutional entrepreneurship and the 
creation of new organizational forms: A multilevel model. Organization Science, 22(1), $60-80$.

Van Kirk, G. (2010). The microconsignment model: Bridging the "last mile" of access to products and services for the rural poor. Innovations, 5(1), 101-127.

Walsh, J. P., Kress, J. C., \& Beyerchen, K. W. (2005). Book review essay: Promises and perils at the bottom of the pyramid. Administrative Science Quarterly, 50(3), 473-482.

Warschauer, M., \& Ames, M. (2010). Can one laptop per child save the world's poor? Journal of International Affairs, 64(1), 33-51.

Webb, J. W., Bruton, G. D., Tihanyi, L., \& Ireland, R. D. (2013). Research on entrepreneurship in the informal economy: Framing a research agenda. Journal of Business Venturing, 28(5), 598-614.

Webb, J. W., Tihanyi, L., Ireland, R. D., \& Sirmon, D. G. (2009). You say illegal, I say legitimate: Entrepreneurship in the informal economy. Academy of Management Review, 34(3), 492-510.

Winter, S. G., \& Szulanski, G. (2001). Replication as strategy. Organization Science, 12(6), $730-743$.

Winter, S. G., Szulanski, G., Ringov, D., \& Jensen, R. J. (2012). Reproducing knowledge: Inaccurate replication and failure in franchise organizations. Organization Science, 23(3), $672-685$.

Yunus, M. (1998). Banker to the poor: The autobiography of Muhammad Yunus, founder of the Grameen Bank. London: Aurum. 
Zoogah, D. B., Peng, M. W., \& Woldu, H. (2015). Institutions, resources, and organizational effectiveness in Africa. Academy of Management Perspectives, 29(1), 7-31.

Myrto Chliova (myrto.chliova@aalto.fi) is an assistant professor of entrepreneurship at Aalto University School of Business in Helsinki, Finland. Her research falls at the intersection of business and development studies, with a focus on the ways that social and sustainable value can be created through entrepreneurial action.

Dimo Ringov (dimo.ringov@esade.edu) is an assistant professor of strategy at ESADE Business School in Barcelona, Spain. He received his Ph.D. in management from INSEAD. His research focuses on the transfer and management of knowledge within firms, such as knowledge embedded in people, organizational practices, routines, or templates, and its impact on firm performance. 